\title{
UM MEMORIALISTA E TANTO
}

Prof. Dr. Afonso Henrique Fávero (UFS)

Com a obra de Pedro Nava, o memorialismo brasileiro viria a conhecer seu momento mais vigoroso, mais comovente, mais cômico, mais admirável, mais completo - e o mais que possa ser - dentro da produção em tal gênero. Desde o seu aparecimento, a recepção crítica não teve dúvida de que ali estava o que de mais importante a literatura de memórias fora capaz de produzir em nossas letras. Porque era muito visível que nunca as possibilidades nesse campo alcançaram balizas tão avançadas, exploração tão exaustiva, adesão tão incomum à matéria recordada, linguagem tão sugestiva e envolvente. Os comentários favoráveis, com elogios enfáticos, tornaram-se mais que abundantes, e o entusiasmo generalizou-se.

Por razões assim, sente-se logo que não é fácil abordar os extensos livros do autor em limites estreitos. A maior dificuldade estará sempre em oferecer uma idéia aproximada daquela infinidade de coisas que nos chegam de forma tão analítica, tão pormenorizada, tão sem preguiça, nas suas memórias copiosas. É certo que dificuldade análoga também existe com relação às obras de qualquer outro de nossos bons memorialistas. Nenhum deles, porém, alcançou com intensidade semelhante e variações múltiplas o mesmo empenho na reconstituição do passado que os seis volumes de Nava nos trazem. Daí a sensação de estarmos diante do ponto mais alto que o memorialismo brasileiro pôde atingir até então.

Opinião, aliás, sem pretensão a nenhuma originalidade, simples de ser expressa, dada a frequência com que é emitida pelos bons leitores do autor. "Nossas letras produziram livros importantes no gênero: o de Joaquim Nabuco, o de Helena Morley, o de Oswald de Andrade, o de José Lins do Rego, o de Graciliano Ramos e vários outros. Nada, porém, que se compare às Memórias de Nava, no estilo, no fôlego, no alcance" (Aguiar, 1998, p. 206). Justamente em razão de tal eminência é que Joaquim Alves de Aguiar observa um avanço significativo da literatura de memórias entre nós. Assim, nesse mesmo compasso, prossegue o crítico a respeito de Nava: 
Pode-se dizer que o escritor, com sua obra, fez o gênero progredir, erguendo-o de sua condição, um tanto subalterna, de literatura de segundo nível. A presença forte de Nava no cenário das nossas letras verdade que se apresenta realçada pelo gosto atual, em 'tempos neoliberais', pelos estudos da subjetividade - pode ter contribuído para estimular o interesse pelo memorialismo brasileiro, que, nos últimos anos, vem merecendo maior atenção da crítica literária. (Aguiar, 1998, p. 206-207)

A consciência de que aquela obra marcava um divisor de águas instalou-se definitivamente em nossa crítica:

Avesso tanto à causalidade histórica linear como à corriqueira construção egocêntrica da narrativa, esse mineiro de Juiz de Fora modelou uma história da cultura brasileira deste século segundo uma perspectiva rigorosamente pessoal, seccionando nossa tradição memorialística em dois momentos: antes e depois da série iniciada com Baú de Ossos. (Dimas, 1991, vol. 1, p. 589)

O valor das memórias de Pedro Nava foi reconhecido de imediato. Antonio Candido, em trabalho que aponta o papel crescente das memórias na literatura brasileira, é dos primeiros a chamar a atenção para a importância de Baú de ossos, logo que a obra aparece: “Baú de ossos, aliás, é singular, por constituir uma estréia literária aos 70 anos e situar o gênero autobiográfico nas alturas raras da verdadeira criação. Não tenho dúvida em dizer que este livro me parece o mais importante dentre os publicados em 1972" (Candido, 1977, p. 12). Em outro trabalho a respeito desse assunto, o mesmo Antonio Candido dedicaria reflexões essenciais sobre a autobiografia na forma de poesia e ficção em autores mineiros. Trata-se de "Poesia e ficção na autobiografia", publicado na obra A educação pela noite e outros ensaios. É nele que Pedro Nava surge na sugestiva companhia de Carlos Drummond de Andrade e Murilo Mendes. Diz o crítico, ratificando o seu favorável ponto de vista acerca do autor:

Antes de abordar o estudo de sua obra conviria lembrar que, se estamos habituados a tratar Drummond e Murilo na categoria dos maiores escritores, a presença entre eles de Pedro Nava pode espantar alguns, porque a sua revelação é recente e as pessoas ainda não se habituaram a aceitar a sua eminência ou admitir que um livro de memórias possa ter a altura das grandes obras literárias. Ora, justamente porque estou convencido desde o primeiro momento de que assim é, ou seja, de que Pedro Nava é um dos grandes escritores brasileiros contemporâneos, não hesitei em situá-lo na devida companhia. Por esta mesma razão tratarei dele mais longamente que dos outros dois, há muito consagrados e gloriosos. (p. 61) 
A obra de Pedro Nava aponta para todos os lados. Trata de tudo e de todos, de ruas, bairros e cidades, de Minas, do Brasil, do mundo, num amplo esforço de indicar a geografia minuciosa de cada lugar de que dá notícia. É também uma erupção de figuras, de retratos, de episódios, de ambientes, de paisagens, de relatos de modos de vida e de transformações de alguns desses mesmos modos, de crises, de sofrimentos, de festas, de alegrias, de informações variadas como culinária, ciência, moda, literatura, arte, medicina, num encadeamento que faz pensar no interminável.

Por isso, avulta uma impressão de impossibilidade quanto à abrangência efetiva de todos os seus aspectos ao nos acercarmos desse universo que tende ao infinito. A memória é um saco sem fundo, como já disse uma vez o próprio autor, e esta é, com efeito, a sensação dominante quando percorremos as múltiplas facetas de sua obra.

De onde viria tamanha disposição para tarefa assim tão imensa e custosa? Como dar conta de tanta coisa relacionada não apenas aos fatos de sua vida - o que já seria matéria suficiente para longa ocupação - mas ainda estender-se pela existência de vários parentes, próximos e distantes, subindo tantas gerações quantas possíveis? E o que dizer das notícias detalhadas de tantos amigos? E mais: dos amigos dos amigos, de suas famílias, de tanta gente que o autor conheceu? Notícias abundantes de várias outras figuras, ora de gente que desempenhou papel de importância em sua vida, ora de gente sem importância alguma? Em meio a toda essa multidão, vamos encontrar relatos e relatos abarcando aspectos fundamentais da sua trajetória de que são exemplos o núcleo familiar, a formação escolar, a vida boêmia e a vida profissional, para ficarmos só nos mais importantes. Estamos diante de uma tarefa notável, sem dúvida! Uma verdadeira história da cultura brasileira a partir de um ponto de vista o mais particular possível, conforme os termos de Antonio Dimas.

Para levar adiante o seu alentado projeto, uma das motivações de Pedro Nava certamente não a única mas uma das mais essenciais - está na enorme identificação que possui em relação à sua terra, que é afinal uma de suas maneiras de manifestar o forte apego às suas origens. Evidente que uma empatia assim não está isenta de uma firme postura crítica, não raro contundente, ainda mais se levarmos em conta a índole artística nada acomodada do autor. De qualquer maneira, o que avulta efetivamente é um 
sentimento vivo de comunhão, de indissociabilidade, de integração absoluta com seu meio, tudo expresso de modo tão afetivo. Aliás, um modo habitual de o autor manifestar-se a respeito de tantos outros temas, como se vê no transcorrer da obra:

(...) Essas áreas, não posso chamar de pátria, porque as não amo civicamente. $\mathrm{O}$ meu sentimento é mais inevitável, mais profundo e mais alto porque vem da inseparabilidade, do entranhamento, da unidade e da consubstanciação. Sobretudo, da poesia... Assim, onde é que já se viu um pouco dágua amar o resto da água? Se tudo é água... Essa é minha terra. Também ela me tem e a ela pertenço sem possibilidade de alforria. Do seu solo, eu como. Da sua água, bebo. Por ela serei comido. (Baú de ossos, p. 111)

Um sentimento caracterizado dessa maneira pode explicar o interesse tão acentuado pela representação do espaço, presente por toda a obra. O estudo de Joaquim Alves de Aguiar orienta-se, por sinal, em torno dessa questão e demonstra de forma consistente a organização das memórias do autor em função de tal aspecto: “(...) não se demora a perceber que Nava é um escritor tremendamente 'espacializado'. É pela reconstituição dos espaços que ele faz voltar o tempo" (Aguiar, 1998, p. 202). Curioso é que o desejo de situar-se com precisão estende-se muitas vezes aos amigos e parentes, mesmo àqueles, dentre esses últimos, que Pedro Nava não chegou a conhecer pessoalmente. Pode estender-se ainda a figuras que sequer tiveram relação direta com ele, como é o caso da negra Sabina, uma vendedora de doces na porta da Faculdade de Medicina à época em que o pai do autor era estudante desse curso no Rio de Janeiro. Tal vínculo, pois, é que de início justifica sua presença nas memórias. Dela falaremos logo mais.

Vejamos primeiro o caso seguinte: o avô paterno de Nava morreu ainda moço em 1880, mais de vinte anos antes do nascimento do autor, que sabia pouco a seu respeito. Isso não o impede de compor de forma minudente o possível caminho que o pai de seu pai utilizava para o trabalho na cidade do Rio de Janeiro. "Não é difícil imaginar como ele faria esse caminho se juntarmos à verdade o verossímil que não é senão um esqueleto de verdade encarnado pela poesia" (Baú de ossos, p. 67). Eis a explicação para compreendermos como o autor se capacitava a detalhar tudo a que não tivera acesso direto: imaginar com verossimilhança. E o resultado é tão convincente que acabamos por esquecer que estamos diante da reconstrução de um passado presumido. A sensação é antes de testemunho, de depoimento de quem vivenciou de fato a 
experiência referida. Tomemos o trecho final de um parágrafo que, sozinho, ocupa nada menos que três páginas cerradas:

(...) Esses caminhos cortavam o centro urbano (...). Neles passava meu avô, acotovelando-se com políticos, portugueses, escravos, marinheiros, barões, crioulas, capoeiras, generais, jornalistas, doceiras, colegiais, quitandeiros, senhoras, fotógrafos, peixeiros e prostitutas; desviando-se dos carris, das vitórias, gôndolas, tílburis, landaus, aranhas, caleches, berlindas e burros sem rabo que atropelavam desordenadamente o solo escorregadio das imundícies, das cascas de frutas, detritos alimentares, baganas, escarros e cusparadas; respirando o cheiro especial do velho centro do Rio de Janeiro - misto de exalações de frutas frescas e frutas podres, da bosta dos estábulos, dos moinhos de café, das barracas de peixe, dos montes de lixo, de leite azedo, de queijo ardido, dos mercados de flores, do perfume das senhoras que passavam rangendo sedas - machadeanas Fidélias, Capitolinas e Virgílias! e do bodum da pretalhada carregando fardos; ouvindo as conversas, os assovios, as cantigas e as obscenidades de uma população que xingava, praguejava e dizia safadezas com o mesmo gosto com que cuspia de esguicho. No meio desse fervilhar de vida passava meu avô para chegar à sua Rua de Gonçalo Gonçalves. (Baú de ossos, p. 69-70)

A riqueza de detalhes impressiona. Lemos as informações mais como se fossem resultado da observação franca do autor que de seu avô propriamente. É como se houvesse uma incorporação profunda de um pelo outro. Ou, então, como se o avô legasse com desembaraço ao neto o conjunto de suas percepções e lembranças da mesma forma que é possível repassar às gerações seguintes caracteres de ordem física. Parece que Pedro Nava quer sugerir exatamente isto. Ele se mostra como produto genuíno de seu meio familiar, capaz de assimilar o espírito de todos os seus predecessores, fazendo-os contemporâneos de si mesmo.

Páginas adiante, o autor esquadrinha um outro caminho do avô, agora em rumo definitivo ao cemitério. O roteiro, como podemos ver, é detalhado:

(...) A $1^{\circ}$ de junho de 1880 meu avô saiu de casa para sempre. Seguiu o mesmo trajeto cotidiano, agora no coche fúnebre que minha avó viu estrelar-se como ameba preta dentro de suas lágrimas, até a Ponte das Laranjeiras. Só que no Largo da Lapa já não entrou por Passeio, mas tomou por Maranguape, Mata-Cavalos, Conde d'Eu, Mata-Porcos, Ponte do Não-Te-Importes, Praia das Palmeiras, Praia de São Cristóvão e Praia do Caju, até o Cemitério de São Francisco Xavier. Ali, na Quadra 38, Sepultura Perpétua 2502, a terra lhe comeria as carnes e o lençol-d'água lhe lavaria os ossos. (Baú de ossos, p. 78)

Referidos com rigor de exatidão, esses espaços demonstram o apego do autor em 
traçá-los e retraçá-los com base em todos os pormenores passíveis de concorrer para a melhor obtenção de tal fim. Não se contenta com dados sumários. É preciso recolher todos os aspectos, todos os ângulos, todas as informações disponíveis. Em decorrência, avulta um dos mais utilizados recursos do estilo de Pedro Nava, que é a enumeração. Esta se apresentará por toda a obra, aludindo a praticamente tudo. Nos trechos acima, é notório o seu emprego na listagem das ocupações das pessoas que passavam pelo caminho do avô, dos veículos a entupir as ruas e as passagens, da sujeira nelas espalhadas, dos odores que exalavam daquelas ruas. A própria nomeação dos logradouros, diligente em ser tão completa quanto possível, constitui também um tipo de enumeração.

Chama ainda a nossa atenção o detalhe específico da visão da avó ao contemplar a saída do coche fúnebre com o corpo do marido. O quadro sugere a capacidade do autor em assumir um ponto de vista diferente do seu. Mas é como se não houvesse diferença alguma, já que estabelece uma identificação assim tão intensa com o olhar pesaroso da avó, a ponto de com ela também enxergar, através de suas lágrimas. Trata-se, pois, de um procedimento inerente à ficção, que o autor não tem dúvida em aproveitar.

Por fim, notamos a presença de um motivo recorrente por meio de termos e sequências constantemente repetidos em todos os volumes das memórias: a terra a comer os corpos. Fenômeno inexorável, contra essa destruição só se pode resistir tentando fixar da melhor forma possível os contornos do passado. De qualquer modo, a consciência, as reflexões e as inúmeras referências a respeito da corrupção da matéria vão ocupar porção significativa no terreno das preocupações do autor. Certamente tais preocupações estão ligadas à profissão médica, atividade exercida ao longo de tantos anos e que lhe dava o conhecimento empírico baseado na experiência constante com a morte.

O ensaio de Davi Arrigucci Jr. capta esse aspecto com precisão, principalmente por evidenciar o vínculo entre o convívio profissional com a morte - a morte que sempre ronda o homem de idade já avançada, caso de Pedro Nava quando começa a escrever as memórias - e o fato de ser ele um herdeiro, por assim dizer, ativo da memória de um grande número de parentes mortos. Diz o crítico: "É da proximidade com a morte que sua narrativa tira a autoridade que a sanciona" (Arrigucci Jr., 1987, p. 92). É preciso, 
portanto, não fugir de nada relacionado ao que a indesejada das gentes impõe. A complexidade do fenômeno faz pensar em degradação e desaparecimento mas também em recuperação pelo caminho da memória: "O materialismo, profundamente incutido em seu espírito, se deixa ver sobretudo no modo como acompanha o destino natural da matéria para a destruição, mesmo quando à espera de ver renascer a vida perdida, por obra da ressurreição da memória" (Arrigucci Jr., 1987, p. 92). Ainda quanto aos aspectos da degradação trazida pela morte, Pedro Nava não se detém ante o que possa parecer medonho. Ao contrário, desce fundo no exame e na nomeação dos acontecimentos.

Nesse sentido, é reveladora em sua prosa a tendência para uma visão estética do mórbido, que não arrepia caminho nem mesmo diante das formas escabrosas da decomposição do corpo, como se quisesse retratar a morte em detalhes, com traços grossos de um naturalismo cru - 'a morte com mau gosto' -, conseguindo captar, no entanto, uma difícil poesia do sinistro. (Arrigucci Jr., 1987, p. 92)

Um dos melhores exemplos quanto a esse aspecto está em Balão cativo. $\mathrm{O}$ autor descreve o seu primeiro e terrível contacto com a decomposição visível da matéria. Tematiza-se aí a deterioração do corpo de um animalzinho, vítima da perversidade de um dos primos de Nava:

(...) Havia em casa um mico, trazido do sertão por meu avô. Um dia mordeu o primo. Foi condenado a ser pendurado pelo pescoço até que a morte sobreviesse. Depois, jogado pelo rabo num canto da chácara. Eu senti a morte do macaquinho como a de gente e decidi dar-lhe sepultura cristã. Levei-o para o outro lado do riacho dos inhames, abri um buraco, forrei de tijolos, fiz a obra de misericórdia e cobri com ladrilhos velhos. Dias depois fui ver como estava e recuei de horror e nojo diante da massa peluda, pegajosa, estufada, sem nome e fervilhando da vida de mil vermes dentro da orquestração das moscas zumbindo. Desprendia um cheiro tão poderoso que me fez cambalear. Era aquilo! A putrefação! Nunca mais a esqueci e, quando estudei Medicina Legal, fixei suas fases sucessivas e hediondas. Transformei esse conhecimento, ai de mim! no suplício indiano que me faz sofrer não só a morte como a desagregação cotidiana e sabida dos meus mortos. Cada dia que passa eu sei como eles vão ficando. É como se os estivesse vendo, hora por hora, através da terra translúcida. Essa vidência me envenena e penso sem parar no festival indecente das vidas que nascerão da morte de minha carne. Pobres, pobres, pobres mortos! Avant tout, votre ventre éclate... Vocês estouram como nas Danças Macabras e no afresco horrendo do Triunfo da Morte, do Campo-Santo de Pisa. Ficam verdes, amarelos, roxos, furta-cor, engordam e murcham, crescem e minguam, emitem gases e o artifício dos fogos-fátuos! Entram em fermentação butírica, ficam rançosos, 
cheiram a camembert e roquefort. Deitam águas, caldos, sangue e sânie, banha mole, choram os próprios olhos, esvaziam as órbitas. Ao fim dum ano, tiram a máscara da cara provisória e a caveira permanente aparece rindo, rindo cada vez mais porque lhe cai a mandíbula e depois ela rola de lado quando já não a sustenta mais o pescoço que se desagrega. Vocês ficam em ossos, ossos que desmoronam. Sobra só aquela espécie de pó de café final, aquele humilde e último cambuí. Os vermes já se foram e as baratas, quando vem o último conviva, a Lucilia tenebrans, a mosca tenebrosa que põe os ovos dentro do crânio esvaziado e cujas larvas se desenvolvem na manteiguinha que ficou de seus pensamentos, suas paixões, suas lembranças, sua memória. Depois elas voam para outros defuntos e, desértico, o gótico esqueleto vai se esfarelar submetido às leis da física e da química que regem os minerais. Os ossos vossos, os meus também... Suplício engenhoso que sofro cada dia, diante de cada morto, pensando neles, passando nos cemitérios - suplício que nasceu ali, abrindo a cova onde apodrecia um bicho... (Balão cativo, p. 62-63)

Note-se que o segmento possui de início uma configuração essencialmente narrativa até o momento em que se dá a visão lúgubre da putrefação. A partir daí, o autor imprime um feitio descritivo, demonstrando o seu saber de homem da ciência a respeito do processo macabro. Repare-se, ainda, que a descrição vem acompanhada de visíveis traços dissertativos, voltados para a reflexão sobre o destino comum a todos os mortos, os "pobres mortos" apostrofados para ser-lhes dirigida a lembrança da condição de degradação e esfacelamento que está inevitavelmente por vir. Nesse sentido, o segmento é bastante representativo da prosa bem-proporcionada de Nava na medida em que conta, descreve, reflete. Nada de extraordinário, contudo, se tal vocação para o emprego dessas formas do discurso não viesse associada a um profundo discernimento na sua mescla. Isto é, o autor sabe lançar mão do recurso adequado no momento justo, narrando, expondo com minúcias, discorrendo, tudo regido por notável senso de equilíbrio, que nos faz nele perceber um dos fatores responsáveis pelo ritmo muito bem cadenciado daquela prosa.

Voltando ao teor predominantemente referencial do segmento, vemos, pois, mais uma das múltiplas alusões encontradiças nas memórias de Pedro Nava: ele, que tanto nos remete para autores diversos da nossa literatura, nos aproxima agora, por força daquela temática de putrefação orgânica, da poesia de um conhecido mestre em tal assunto. Aproximação, por sinal, já percebida e comentada por estudiosos de sua obra, como é o caso do médico e escritor Raimundo Nunes: "Verdade é que a temática da morte e suas circunstâncias dominam, em grandes espaços, as preferências literárias do 
Nava. Nesse aspecto, tem algo a ver com as constantes funéreas da poesia de Augusto dos Anjos" (Nunes, 1987, p. 66).

A respeito dessas tantas alusões, vale abrir um parêntese para dizer que não é difícil, com efeito, encontrar pontos comuns entre a prosa do autor e várias dimensões de nossa produção intelectual. Claro que suas memórias trazem um universo sem fim de referências a toda a cultura ocidental, a começar pela Bíblia. Também é preciso reconhecer que não são apenas as obras literárias - sobretudo de autores franceses, portugueses e ingleses - que evidenciam o seu conhecimento nesse plano. Impressiona do mesmo modo a sua grande desenvoltura no campo das artes plásticas - com a menção sempre adequada aos principais nomes da pintura - e no campo do cinema em seus primórdios - com sua devoção a Charles Chaplin. Para ficarmos na esfera doméstica, vale lembrar inicialmente um clima comum entre a prosa de Pedro Nava e a poesia de Manuel Bandeira, Carlos Drummond de Andrade, além de outros poetas do Modernismo. Sem surpreender, tal parentesco chega a ser mesmo natural em face da sua militância modernista na juventude. O mais notável é que sua obra aponta também para Castro Alves e certos poetas românticos, especialmente os de tom elegíaco acentuado; para certos traços de nossa poesia barroca, com imagens escatológicas à maneira de Gregório de Matos, por exemplo; às vezes, para a expressão classicizante dos parnasianos; sem contar ainda imagens com algo de etéreo e de abstracionismo que lembram os simbolistas, ou uma temática de feição idílica voltada para aspectos da natureza, própria dos árcades. Se a obra do autor apresenta tal proximidade com a poesia brasileira, com a nossa prosa de ficção o parentesco torna-se mais patente ainda. Um trabalho nesse sentido revelaria os inúmeros pontos de contacto entre as memórias de Pedro Nava e o percurso do romance brasileiro. Mostraria também as relações que possam ter com toda a literatura dos viajantes do período colonial. Acompanha a seu modo os esforços de explicação do Brasil empreendidos pelas ciências humanas, sobretudo a partir da década de 30. E, obviamente, é de se ver a sua vinculação profunda com a pequena mas já consistente tradição do memorialismo brasileiro. Enciclopédica como poucas, o que se quer dizer é que a prosa de Pedro Nava, por essa tangência não só com a literatura mas com toda a cultura brasileira, tende a aspirações totalizantes, podendo assim ser tomada como uma espécie de súmula de toda a nossa vida espiritual. 
Mencionei em parágrafo anterior o empenho do autor quanto à melhor fixação dos contornos do passado. É provavelmente por essa razão que Pedro Nava se esmera em definir todos os espaços de um jeito tão minucioso e com pretensões de fidelidade quase absoluta, pois apenas assim o memorialista alcançaria, porventura, um resgate mais eficaz das coisas no tempo.

Com a mesma motivação, podemos perceber esmero semelhante nas descrições circunstanciadas de uma infinidade de ambientes e objetos, invariavelmente ligados à lembrança de personagens do passado. Para uma idéia do processo, veja-se que, quando nos oferece a visão de um dos quartos da casa ocupada pela família à Rua Aristides Lobo 106, no bairro carioca do Rio Comprido, as particularidades ali relacionadas chegam a extremos de detalhamento. Trata-se do quarto de uma irmã de seu pai (tia Candoca), no qual se guardou literalmente, por algum tempo, um baú de ossos: os da prima Alice, morta ainda pequena em Juiz de Fora, filha daquela tia. Assim o autor enumera a sua mobília:

Duas camas, a de minha tia e a da Maria, quando vinha do SacréCoeur. Dois armários imensos. Um lavatório antigo, de madeira escura e tampa de mármore vasada para receber uma bacia de prata desirmanada do jarro extraviado, que fora substituído por um de porcelana azul, com medalhões representando cenas pastorais. (Baú de ossos, p. 363)

A referência ao jarro de porcelana, substituto do outro de prata, sem deixar de lembrar-lhe os detalhes dos medalhões com suas cenas pastorais, é com efeito de um requinte de reminiscência incomum em outras obras do gênero. Mas não na obra de Pedro Nava. Ali, isto é método. Tais descrições constituem parte substancial daquilo que poderíamos chamar, quem sabe, de desvelo de contextualização. Todos os elementos recordados parecem necessários à recomposição do cenário, sem os quais o mesmo não estaria perfeito para a sua repovoação, por assim dizer.

(...) No 106, entre outras coisas, figuravam um porta-retratos, com o de minha avó, e um marquês de porcelana - hoje em minha casa e trazendo para ela restos daquelas em que estiveram. Diante desses objetos houve aniversários, noivados, casamentos, velórios. Foram mudados de lugar, lavados, brunidos por mãos mortas. Estiveram no Rio Comprido, na Tijuca, no Icaraí, na Urca, no Leblon, em Copacabana e trazem para minha casa da Glória um pouco das casas sovertidas de minha gente. Sobre as mesinhas dos fumantes, junto dos 
cinzeiros, nova coleção de portas. Porta-cigarros. Porta-charutos. Porta-caixa de fósforos. Complemento para os tabagistas: as duas escarradeiras dum tempo em que havia o hábito de não fumar sem cuspir. O espelho da parede. O quadro com o retrato do avô. Sua presença. Pedro da Silva Nava. É no meio destes objetos familiares e à luz das janelas abertas que vejo a figura dos amigos que frequientavam nossa sala. (Baú de ossos, p. 320)

O segmento nos auxilia a compreender melhor esse esforço do autor em não economizar nas minúcias, que formam matéria indelevelmente associada aos personagens antigos que deseja resgatar para o presente. Concebidas com propósito assim tão descritivo, as sequências de períodos, muitos deles compostos apenas de sintagmas nominais como que para ampliar-lhes a capacidade definidora, parecem indicar a importância de todas as coisas lembradas. É como se o nome do avô, citado em meio àquela sequência e lá justaposto em pé de igualdade com as demais menções, só pudesse alcançar o realce merecido se cercado dos vários objetos que um dia lhe disseram respeito. Objetos que, como se vê pelo registro do autor, possuem a dignidade de ter testemunhado a história da família, tendo sido manipulados por "gente há muito desfeita em pó" (Balão cativo, p. 94). Disseminada por toda a obra, essa espécie de coesão entre objetos e ambientes de um lado, e de pessoas de outro, encontra seu esclarecimento mais apropriado na concepção de Proust, transcrita por Nava no último volume das memórias:

Je trouve très raisonable la croyance celtique que les âmes de ceux que nous avons perdus sont captivés dans quelque être inférieur, dans une bête, un végétal, une chose inanimée, perdues en effet pour nous jusqu'au jour qui pour beaucoup ne vient jamais, où nous trouvons passer près de l'arbre, entrer en possession de l'objet qui est leur prison. Alors elles tressaillent, nous appelent, et sitôt que nous les avons reconnues, l'enchantement est brisé. Delivrées par nous elles ont vaincu la mort e reviennent vivre avec nous. ( $\mathrm{O}$ círio perfeito, $\mathrm{p}$. 292)

A partir daí, já incorporado na figura de seu alter ego, o médico José Egon Barros da Cunha, Pedro Nava expande-se em ilações que visam a confirmar tal vínculo. Assim é que, imediatamente após a citação de Proust, continua o autor no mesmo compasso:

(...) O médico estremeceu e sentiu que essa coisa luminosa de Proust está na origem do que diz Guimarães Rosa - que os mortos se encantam. Mas a particular importância da concepção é que a partir dela vem todo o processo da associação reminiscente da teoria da madelaine. Sugeriu ao médico que esse encantamento é que faz os objetos velhos sagrados porque neles muitas pessoas se encantaram (num pedaço inachável mas presente como molécula marcada, incluída na matéria dum cristal). Não só pessoas mortas, mas aquelas 
ainda vivas como elas eram nos remotos. Idéias, lembranças que tornam cada quina, cada pedaço dum móvel, duma casa, duma rua, duma praia - outra madelaine. (O círio perfeito, p. 292)

A mobília familiar que Pedro Nava pôde conservar em sua casa é, por conseguinte, fonte constante de recordações. Faz, por exemplo, com que ele pense não só nas pessoas como também em outros objetos dos cenários antigos. Ou, por outra, revela a íntima ligação que possa haver entre pessoas e objetos. Diz o autor sobre um aparador de madeira clara:

Por ele se imagina o guarda-louça que o acompanhava e o tamanho da mesa patriarcal da sala-de-jantar de meus bisavôs, onde batia este relógio de repetição cujas horas estou ouvindo e cujos ponteiros negros vêm há cento e quarenta anos rodando sobre nossos nascimentos, batizados, casamentos, mortes e enterramentos. (Baú de ossos, p. 43)

É de se ver, pois, que tais objetos possuem algo de mágico por estabelecer vínculo assim tão forte com o passado. Ainda mais quanto ao relógio de repetição, esse símbolo inapartável do tempo e de seu desenrolar contínuo. Nava voltará a referir-se ao relógio na primeira parte de Galo-das-trevas, num dos momentos mais pungentes de toda a sua obra:

O relógio armário vacarmiza com seus tic - estalos - tac a tempos iguais do pêndulo cá e já logo lá e a lua do mostrador me manda além das três e meia das horas, o sem-número de caras que as procuraram no tempo e que não procuram mais saber quantas são. Se fosse uma raridade de antiquário, não me diria nada. Mas é um de armário que bate as horas para minha gente há mais de cem anos. (Galo-das-trevas, p. 28)

Nesse capítulo inicial de Galo-das-trevas, marcado por um tom fortemente lírico, o autor faz uma espécie de balanço do que escreveu até então, promovendo a passagem do foco narrativo para uma terceira pessoa, que cuidará da trajetória de José Egon Barros da Cunha, seu alter ego há pouco citado. Por ora, vejamos que a figura do avô paterno uma vez mais assume relevo por meio da alusão ao móvel onde repousou seu corpo já sem vida: "Nesse canapé esteve esticado meu avô, no dia 31 de maio de 1880, antes de o deitarem no caixão de onde tirei seus ossos de bronze sessenta e cinco anos depois" (Baú de ossos, p. 43). Assim, muitos desses objetos acabam por desempenhar a função de verdadeira memória documentada, à semelhança das cartas, diários, documentos familiares, fotografias etc., que o autor declaradamente utilizou na composição de suas reminiscências. 
O empenho em resgates como os tantos que vemos no decurso da obra é naturalmente acentuado com relação aos inúmeros familiares do autor. Mas, mesmo quando referente a figuras não tão próximas ou até àquelas a quem ele não conheceu pessoalmente, a narrativa também costuma ganhar encanto particular, pois a sensação é sempre a de uma espontânea relação de intimidade.

Ao acompanhar em Baú de ossos as etapas do curso médico de seu pai, Pedro Nava faz alusões a um grande número de mestres e companheiros desse curso, traçandolhes o perfil, expondo-lhes os temperamentos, lembrando as estroinices dos alunos, e assim oferecendo já uma antecipação do que seria a narrativa de sua própria formação na Faculdade de Medicina de Belo Horizonte, um dos temas centrais de Beira-mar.

A certa altura, começa a relatar a história de Sabina, a vendedora de doces que encontrava seus fregueses nos alunos da escola em que estudara o pai do memorialista. Nava dedica uma página antológica a tal figura, que não pôde conhecer e de quem obteve notícias por meios indiretos. "Entre uma aula e outra, os estudantes iam para a porta conversar, olhar o mar, descarrilar os bondes, namorar as lavadeiras de Tanagra, quebrar a cara dos burros-sem-rabo ou aglomerar-se em torno ao tabuleiro da Sabina divina, saboreando suas cocadas e punhetas" (Baú de ossos, p. 215). Apressa-se em explicar: "Esse último nome era o de uma gostosura amassada com a mão - um doce, bem entendido! - feito com tapioca, coco e assadinho no borralho" (Baú de ossos, p. 215). Por causa do vocábulo de sentido ambíguo e por isso bastante cômico naquela situação, pelo emprego de um termo avaliativo como "gostosura", pelo diminutivo "assadinho" a indicar afetividade e, claro, pelo epíteto "divina", já se vê a forte adesão que o narrador demonstra em relação à vendedora. $O$ andamento do texto vai confirmando essa sensação inicial. Prodígio de síntese, a descrição que ele faz da mulher em apenas um período já é o suficiente para comprovar tal empatia: "A Sabina era uma negra fabulosa, saída, com seu colo de ébano, sua bunda de jacarandá e seus olhos de jaboticaba, de um Rugendas ou de um Debret” (Baú de ossos, p. 215). Descrita por meio dessas belas metáforas - figura de linguagem largamente utilizada por Nava nas memórias -, a mulher adquire, assim, a condição de personagem de uma obra de arte, alçada a modelo exemplar daqueles pintores. Para a deferência ser ainda maior, o narrador reproduz literalmente o pregão com que ela anunciava sua presença no local em que dispunha seus doces à venda. $\mathrm{O}$ relato da situação possui forte apelo visual, 
como se testemunhada por ele, conforme podemos notar no segmento seguinte:

(...) Era amiga dos estudantes e tinha para se anunciar pregão composto por ela e que ela cantava, balançando como as ondas que iam e vinham e batiam no cais, entre as portas da Faculdade e as escadas da Misericórdia.

Sou a Sabina. Todas as tardes,

Todas as tardes sou encontrada,

Sou encontrada lá na calçada

Lá na calçada da Academia,

Da Academia de Medicina... (Baú de ossos, p. 215)

Não é demais insistir em que nada do que é registrado a respeito de Sabina configura resultado direto das reminiscências do autor. São histórias de que ouviu falar, mas apresentadas de maneira tal que parecem fruto de sua própria observação. Determinadas imagens remanescentes do cenário, e por isso constatáveis a posteriori, auxiliam na recuperação das imagens que se foram. Isto é patente sobretudo em "ondas que iam e vinham e batiam no cais", movimento constante do mar já tornado em símbolo de perenidade, com o polissíndeto reforçando a sensação das coisas que se repetem e tendem à duração sem fim, como deveria ser, afinal de contas, a figura de Sabina com seus doces admiráveis.

Aí está um dos segredos do autor na recomposição do passado. A menção sistemática a espaços, ambientes e objetos revela-se, como vemos, um procedimento recorrente e de importância decisiva em suas memórias. Os detalhes envolvendo o caso de Sabina dão, de fato, essa impressão de um testemunho sem intermediários:

Ora, um belo dia, nada de Sabina, de seu chale da Costa, de suas saias de goma, de suas chinelas sonoras, de seu pregão merencóreo. Nada de cocadas, nada de cuscuz, nada de punhetas. Nada. A autoridade sanitária tinha proibido os tabuleiros e um tenente de polícia atrabiliário tinha rapado o da Sabina. Os estudantes deram outro e, quando o meganha voltou, encontrou a negra garantida pela Faculdade. Começou a inana. Pode! Não pode! Fora, puto! Ordens são ordens! Merda pras ordens! Não pode! Pode! Houve pescoções, bengaladas, golpes de refle. Cavalaria e rolha para cavalo pranchear. Tentativa de invasão e defesa da cidadela com garrafões de ácido sulfúrico despejados por Guahiba Rache, em cima dos soldados. Finalmente os tiros. Houve feridos e parece que mortos. A revolta ficou chamada a sabinada e terminou porque aconteceu que o Chefe de Polícia não era integralmente cretino e mandou que tornassem ao lugar negra e tabuleiro. Ela voltou e ouviu-se novamente seu pregão todas as tardes. Todas as tardes lá na calçada, lá na calçada da 
Academia, da Academia de Medicina (Essa história eu a ouvi de um contemporâneo de meu Pai, Levy Coelho da Rocha, médico em Belo Horizonte. Se não estiver conforme, outro, do tempo, que a conte melhor). (Baú de ossos, p. 215)

Vários pontos chamam nossa atenção no trecho acima. Primeiramente, os pormenores dos trajes de Sabina, produto da interferência imaginativa do autor, sem dúvida. Depois, o "nada" anafórico do segundo período sugerindo as repetições que o seu pregão comportava. Em seguida, o discurso direto livre a mimetizar a discussão entre estudantes e polícia, o que revela a disposição daqueles na defesa do trabalho da vendedora. Tal discurso já se vê que também é resultado daquela interferência imaginativa e, mais que isso, um expediente a contribuir naquela repovoação dos cenários evocados de que falamos atrás. Por fim, a esperada cumplicidade do autor quanto a uma solução do caso favorável à Sabina, indicada entre outras coisas pela bonita e engenhosa reprodução da anadiplose que marcava aquele pregão formulado com recursos poéticos. Não nos esqueçamos ainda da frase parentética, que desafia divertidamente algum ouvinte da história a contá-la melhor.

Aliás, esse remate clássico de casos narrados numa roda de ouvintes será retomado páginas adiante, quando se rememorarem os tempos de Rosa, que, ao contrário de Sabina, o autor conheceu muito bem. Tratava-se de uma negra criada por sua avó materna, dotada de memória prodigiosa, "que registrava tudo para sempre e de modo indelével" (Baú de ossos, p. 239), Rosa era consultada sobre qualquer matéria que demandasse tal faculdade, respondendo a tudo sem hesitar. Para as crianças, porém, o grande interesse que despertava estava em sua capacidade de contar enredos famosos: "Mas o melhor é que Rosa, além de ser um canhenho vivo, sabia, ouvidas não sei onde nem de quem, todas as histórias de Andersen, Perrault e dos irmãos Grimm" (Baú de ossos, p. 239). Aos inúmeros personagens das narrativas de Rosa o autor associava figuras de Juiz de Fora, suas conhecidas, aproximação que certamente corresponde à sua tendência para convergir memória e ficção.

Sobre aquele remate tradicional das histórias, o de Rosa era aplicado quando se cansava de contá-las. Ela o expressava da seguinte maneira: “(...) 'entrou pelo cu dum pinto, saiu pelo cu dum pato, quem quiser que conte outra'. Sic. Era assim mesmo. A Rosa ignorava a forma vernácula e delicada lembrada por Machado no Esaú e Jacó: / 
Entrou por uma porta, saiu pela outra, manda el-rei nosso senhor que nos conte outra" (Baú de ossos, p. 239). Como significasse o encerramento das histórias, uma conclusão assim, apesar de hilária, tornava-se decepcionante para os pequenos ouvintes. Pior que isso só a engabelação do "tá passando" interminável, recurso extremo de Rosa para burlar a atenção das crianças sonolentas:

(...) O pastor que era lindo como o sol e tinha um rebanho enorme de gansos para passar a ponte do Botanágua. Chegou à ponte, pediu licença ao guarda e começou a passar os gansos. Parava a rapsoda, para ver se o menino dormia. Ele voltava dos abismos reclamando. E depois? Só posso contar depois dos ganso passá... Tá passando... Pausa. E depois? Rosa. Tá passando... assim, não! Rosa. Tá passando... Tá passando. Eu dormia com os gansos passando. Os gansos um dia passaram todos como os dias que não voltam mais do Chico meu filho... Ah! E agora? Rosa... (Baú de ossos, p. 240)

Esse Chico meu filho, parente de Pedro Nava, era o poeta Brant Horta, cuja mãe, a prima Mariquinhas, só o chamava pela expressão conjugada: nunca "Chico" ou apenas "meu filho", era Chicomeufilho, autor de uns versos à maneira de Casimiro de Abreu, que Rosa trazia decorados, recitando-os de imediato, "ali na bucha!” (Baú de ossos, p. 239), quando instada a fazê-lo. Repare-se uma coincidência, pois o nome de Rosa é o mesmo daquela outra contadora de histórias: a Rosa dos poemas de Manuel Bandeira. Sua figura torna-se assim um meio pelo qual o clima da poesia do autor pernambucano acaba ecoando aqui nessas memórias, às vezes até mesmo de forma direta, como é o caso de "Profundamente", citado como epígrafe em Baú de ossos. E, claro, ecos também de Drummond por meio da expressão "E agora? Rosa...", indagação que, surgindo após o encerramento de um ciclo, isto é, lembrando a finitude de todas as coisas, nos remete logo para o seu famoso “E agora, José?".

Pedro Nava, como vemos, demonstra grande ternura por Rosa, cujo engenho não era mesmo pequeno. Isto se evidenciava na interpretação muito particular que ela fazia da história cantada de uma ex-donzela chamada Juliana, enganada pelo namorado. Tratava-se de antiga história européia, que adaptara para as paisagens de Juiz de Fora. Sobre esses seus dotes escreve fascinado o autor:

(...) O talento cênico da negra era fantástico e ela interpretava genialmente, à mineira, cantiga portuguesa ou coisa erudita tornada canto popular. Ah! Rosa, rosa nas trevas, rosa de trevas, rosa de amor, purpúrea e bela, rosa para nós há tanto desfolhada na aridez sepulcral dos nossos corações, rosa da infância, rosa unicamente nominativa, jamais declinável. Anos depois ela me descobriu na Rua da Glória e 
veio me visitar. Estava gorda, mãe de família e dera para beber. Só que tinha a mesma constelação antiga das estrelas dos olhos e da estrela da face. Rosa, você toma uma cervejinha? Tomo, seu Pedrinho, mas só se for entremeando com cachaça, para respaldar. Eu mesmo servi minha negra e quando ela ficou no ponto, taramelando e vaga, comecei a testá-la. Rosa! que dia morreu minha avó? Quatro de setembro de 1913. Como é que se chamava a madrinha de minha Mãe? A de batismo era Dona Mariquinhas Vidal de Andrade Santos e a de crisma Dona Mariquinhas Brant Horta. Rosa! Rosa! Agora a Juliana. Ela encenou, contracenou e cantou. Mas onde estavam, onde? as flores-d'antanho. (Baú de ossos, p. 244)

Como não nos lembrarmos do "Onde estão todos eles?", verso do já citado "Profundamente", de Manuel Bandeira? Por aí é que vemos a profunda adequação entre esses temas e a epígrafe situada no início do segmento - "Mais oú sont les neiges d'antan?" (Baú de ossos, p. 238), verso de François Villon - e refletida na última frase da citação acima. A presença desses autores indicaria desse modo uma orientação ao leitor quanto ao espírito da narrativa, segundo a observação de Davi Arrigucci Jr.: "Assim, desde o princípio, se insinua uma direção de leitura, como se estivéssemos diante de uma longa narrativa elegíaca, dominada pela 'pergunta sem resposta' do 'onde estão todos eles?"' (Arrigucci Jr., 1987, p. 93).

No ensaio que traz justamente esse título - "Pergunta sem resposta" -, Augusto Meyer aborda o topos do ubi sunt?, em que figuram, não por acaso, nomes como os citados por Pedro Nava: Villon e Bandeira. Diz Meyer sobre a pergunta: "Eco irônico, é uma interrogação que na verdade não espera resposta alguma, e apenas se ouve ao longe, velada de uma serena surdina de entressonho" (Meyer, 1986, p. 85). Tal pergunta Nava a repetirá em vários momentos de sua obra, tornando-se um dos sintomas mais fortes de sua busca do temps perdu.

Para resumir, vemos que descrições meticulosas de espaços, referências tão afetivas a pessoas cujo conhecimento ora se dera diretamente ora por meio de histórias que lhe vieram de outras fontes, alusões a poetas que também fixaram com grande adesão o tema da passagem do tempo, discursos diretos livres em profusão, como que a querer presentificar os ausentes, vemos que todos esses elementos, enfim, foram amplamente utilizados na composição da obra. Com tais recursos é que Nava logra atingir o imenso êxito na reconstituição do passado. 
Pelas razões assinaladas - e por outras mais que nem chegaram a ser objeto dessas reflexões - é que a obra do autor consagrou-se como o monumento literário mais notável do memorialismo brasileiro, sem similares em qualquer época, sem nada que possa fazer-lhe frente.

Como ponto de encontro, as memórias de Pedro Nava reúnem praticamente tudo o que a tradição do nosso memorialismo apresentou de melhor, tanto do ponto de vista da expressão quanto da matéria. Para uma idéia sucinta de sua marcha, vemos que ele traz para o conjunto da obra quase toda a temática a animar os demais memorialistas que o antecederam em nossas letras: o Brasil Imperial e a passagem para a República; a escravidão; a Primeira Guerra Mundial; a gripe espanhola, noticiada por tantos memorialistas; episódios pitorescos como a visita ao Brasil do Rei Alberto I e da Rainha Elisabeth da Bélgica; o Movimento Modernista; episódios políticos isolados como o conflito em Montes Claros que envolveu Melo Viana, então Vice-Presidente da República; a Revolução de 30, especialmente os reflexos do embate em Belo Horizonte; o Movimento Constitucionalista de 32, além de uma série imensa de acontecimentos que vão compondo um curioso e instigante panorama da vida nacional. "Uma lição de vida, mas sobretudo uma lição de Brasil”, nas palavras de Francisco de Assis Barbosa.

Tal abrangência efetiva-se igualmente nas formas de veicular a matéria das memórias. Existem nos demais autores matizes predominantes que, dependendo da perspectiva adotada, fazem com que suas obras assumam um caráter ou mais lírico ou mais épico ou ainda, em determinadas parcelas da obra, até mais dramático. Pedro Nava circula por todas essas esferas, imprimindo em relação ao tema do momento a forma que melhor lhe convém. Assim, sua obra mostra-se multifacetada também nos modos de exprimir, pois revela capacidade de mover-se entre os diferentes meios de expressão de acordo com o que solicita a matéria.

A criatividade, a adequação, a liberdade, esse espírito em busca de totalidade, todas essas qualidades enfim que procuramos acompanhar no transcorrer deste trabalho é que garantem à obra de Pedro Nava o grande reconhecimento alcançado no mundo das nossas letras. 


\section{REFERÊNCIAS}

\section{Obras de Pedro Nava:}

Baú de ossos. 4a. ed. Rio de Janeiro: José Olympio, 1974.

Balão cativo. 2a. ed. Rio de Janeiro: José Olympio, 1974.

Chão de ferro. Rio de Janeiro: José Olympio, 1976.

Beira-mar. 3a. ed. Rio de Janeiro: José Olympio, 1985.

Galo-das-trevas. 3a. ed. Rio de Janeiro: José Olympio, 1981.

O círio perfeito. Rio de Janeiro: Nova Fronteira, 1983.

\section{Demais obras:}

AGUIAR, Joaquim Alves de. Espaços da memória - um estudo sobre Pedro Nava. São Paulo: Edusp; Fapesp, 1998. (Col. Ensaios de Cultura)

ARRIGUCCI JR., Davi. Enigma e comentário. São Paulo: Companhia das Letras, 1987.

CANDIDO, Antonio. A educação pela noite e outros ensaios. São Paulo: Ática, 1987.

. “A Literatura Brasileira em 1972”. Revista Iberoamericana, Pittsburgh: Universidade de Pittsburgh, vol. XLIII, n. 98-99, jan.-jun. 1977.

DIMAS, Antonio. "Memória e pudor". In Anais do 2o. Congresso Abralic. Literatura e Memória Cultural. Vol. I. Belo Horizonte: Associação Brasileira de Literatura Comparada, 1991, p. 589-593.

MEYER, Augusto. Textos críticos; seleção e introdução de João Alexandre Barbosa. São Paulo: Perspectiva; Brasília: INL, Fundação Nacional Pró-Memória, 1986. (Col. Textos)

NUNES, Raimundo. Pedro Nava: memórias. São Paulo: Ateniense, 1987.

RECEBIDO EM: 03 de novembro de 2011 APROVADO EM: 09 de dezembro de 2011 